\title{
Dentist's child view and psychological approach
}

\author{
Abordagem psicológica e visão do dentista em crianças pré escolares \\ La visión del niño del dentista y el enfoque psicológico
}

Received: 07/12/2021 | Reviewed: 07/17/2021 | Accept: 07/21/2021 | Published: 07/28/2021

\author{
Karine Takahashi \\ ORCID: https://orcid.org/0000-0002-6192-6398 \\ University of Western São Paulo, Brazil \\ E-mail: karinetakahashi@gmail.com \\ Camila Teresinha Nascimento de Araujo \\ ORCID: https://orcid.org/0000-0002-8578-8727 \\ University of Western São Paulo, Brazil \\ E-mail: camilat.odonto@outlook.com \\ Lara Rúbia Miotto Ferreira dos Santos \\ ORCID: https://orcid.org/0000-0002-7917-7401 \\ University of Western São Paulo, Brazil \\ E-mail: miotto.lara@gmail.com \\ Natani Carla Cristovam \\ ORCID: https://orcid.org/0000-0001-5121-4728 \\ University of Western São Paulo, Brazil \\ E-mail: natani.carla.cris@ hotmail.com \\ Joselene Lopes Alvim \\ ORCID: https://orcid.org/0000-0002-8414-3935 \\ University of Western São Paulo, Brazil \\ E-mail: joalvim@unoeste.br \\ Geórgia Rondó Peres \\ ORCID: https://orcid.org/0000-0002-8912-5381 \\ São Paulo State University, Brazil \\ E-mail: drageorgiarp@gmail.com \\ Ana Bheatriz Marangoni Montes \\ ORCID: https://orcid.org/0000-0002-5846-2502 \\ University of Western São Paulo, Brazil \\ E-mail: anabheatriz@unoeste.br \\ Heitor Ceolin Araujo \\ ORCID: https://orcid.org/0000-0001-5749-592X \\ São Paulo State University, Brazil \\ E-mail: heitor.ceolin@unesp.br
}

\begin{abstract}
In the routine care of the child, professional can come across situations in which the child shows aversive, and avoiding personal contact, especially in cases of first appointment. This study aims to analyze the children's perception about dental surgeon through drawings analysis and verbal characterization. The sample consisted of 108 children aged between 5-11 years of both genders, 59 were patients of pediatric dentistry clinic of west Sao Paulo Presidente Prudente, and 49 students of the school of Tertuliano de Area Leão located in the city of Santo Anastacio, SP, Brazil. Children made a drawing expressing their vision about dental surgeon and the dental environment. The collected drawings were interpreted by a psychologist and grouped in Microsoft Office Excel spreadsheet and performed a statistical analysis using Fisher's exact test, logistic regression and regression simple logistics. Through this study it was possible to observe that $57,6 \%$ children analyzed in clinic of pediatric dentistry of Unoeste presented pleasant vision results of dental care, while $42,4 \%$ showed a hostile result, these being, mostly female children gender. In school, only $24,5 \%$ children presented pleasant result and $75,5 \%$ showed hostile result, the absence of gender difference. It is concluded that there was a statistically significant difference among the groups, and female gender children showed up more aversive.
\end{abstract}

Keywords: Dental anxiety; Child psychology; Drawing; Fear; Pediatric dentistry.

\section{Resumo}

No atendimento rotineiro à crianças, o profissional pode se deparar com situações em que a criança se mostra aversiva, evitando o contato pessoal, principalmente nos casos de primeira consulta. Este estudo tem como objetivo analisar a percepção de crianças sobre o cirurgião-dentista por meio da análise de desenhos e caracterização verbal. A amostra foi composta por 108 crianças com idade entre 5 e 11 anos de ambos os sexos, 59 eram pacientes da clínica 
de Odontopediatria da Universidade do Oeste Paulista de Presidente Prudente, e 49 alunos da escola de Tertuliano de Area Leão localizada na cidade de Santo Anastácio, SP, Brasil. As crianças fizeram um desenho expressando sua visão sobre o cirurgião-dentista e o ambiente odontológico. Os desenhos coletados foram interpretados por uma psicóloga e agrupados em planilha do Microsoft Office Excel e realizada análise estatística por meio do teste exato de Fisher, regressão logística e regressão logística simples. Por meio deste estudo foi possível observar que 57,6\% das crianças analisadas no ambulatório de odontopediatria da Unoeste apresentaram resultados de visão agradáveis no atendimento odontológico, enquanto $42,4 \%$ apresentaram resultado hostil, sendo, em sua maioria, crianças do sexo feminino. $\mathrm{Na}$ escola, apenas $24,5 \%$ das crianças apresentaram resultado agradável e 75,5\% apresentaram resultado hostil, ausência de diferença de gênero. Conclui-se que houve diferença estatisticamente significativa entre os grupos, sendo as crianças do gênero feminino mais aversivas.

Palavras-chave: Ansiedade ao tratamento odontológico; Psicologia da criança; Desenho; Medo; Odontopediatria.

\section{Resumen}

En la atención de rutina al niño, el profesional puede enfrentarse a situaciones en las que el niño es aversivo, evitando el contacto personal, especialmente en los casos de primera consulta. Este estudio tiene como objetivo analizar la percepción de los niños sobre el dentista a través del análisis de dibujos y caracterización verbal. La muestra estuvo conformada por 108 niños de entre 5 y 11 años de ambos sexos, 59 eran pacientes de la clínica de Odontopediatría de la Universidade do Oeste Paulista en Presidente Prudente, y 49 estudiantes de la escuela Tertuliano de Area Leão ubicada en la ciudad de Santo Anastácio, SP, Brasil. Los niños hicieron un dibujo que expresaba su visión del dentista y el entorno dental. Los dibujos recopilados fueron interpretados por un psicólogo y agrupados en una hoja de cálculo de Microsoft Office Excel y el análisis estadístico se realizó mediante la prueba exacta de Fisher, regresión logística y regresión logística simple. A través de este estudio se pudo observar que el 57.6\% de los niños analizados en la clínica de odontopediatría de Unoeste tuvo agradables resultados visuales en el cuidado dental, mientras que el $42.4 \%$ tuvo un resultado hostil, siendo la mayoría hijos del sexo femenino. En la escuela, solo el 24,5\% de los niños tuvo un resultado agradable y el 75,5\% tuvo un resultado hostil, sin diferencia de género. Se concluye que hubo una diferencia estadísticamente significativa entre los grupos, siendo las niñas más aversivas.

Palabras clave: Ansiedad al tratamiento odontológico; Psicología infantil; Dibujo; Miedo; Odontología pediátrica.

\section{Introduction}

In routine care of the child, professional may encounter situations in which the child is aversive and avoiding personal contact, especially in cases of first appointment, in which the child is presented for the first time to this professional. It is necessary to establish a relationship of trust between professional and patient. When faced with the manifestation of fear by the child in the eminence of a dental treatment, the treatment is possible by an adequate management by the dentristry (Patti \& Meneses, 2005). Children whose parents show fear to dental appointment can also express more fear too (Cardoso \& Loureiro, 2008).

Dental fear is widely recognized for its harmful effects, early identification of these children helps to control dental fear influencing the improvement of oral health (Laureano et al., 2020). In most people dental treatment is related to pain and stress, mainly for children. This situation can cause abscense of patient of dentist's room, which can aggravate dental needs (Stutz, 2011). The origin of fear of the dentist in children has several factors, often related to personality, previous experiences, increased fear, age and gender (Oba, Dugergil \& Sonmez, 2009).

Usually younger children are more anxious than older ones, probably because they have not yet experienced dental care visit (Oliveira, Moraes \& Cardoso, 2012). Significantly, mild fear is normal for child development, but when it exceeds disproportionately, problems can appear. Fear can be differentiated into exogenous and endogenous, where exogenous refers to direct or indirect anterior trauma (Salem, Kousha, Anissian \& Shahabi, 2012). Most dental procedures for a child can be seen as a painful threat (Pala, Nuvvula \& Kamatham, 2016).

Preventive, regular and non-painful visits reduce anxiety for child development. In this way negative effects dicrease, and consequently increase pleasant effects related to the professional (Milson, Tickle, Humpris \& Blinkrom, 2003). Once previous fear of the dental consultation is overcome, the children create a bond with the dentist and even approve to carry out the consultations, mainly for short and non-painful visits (Oliveira, Moraes \& Cardoso, 2012). 
Most children when they can't cope with their fears will resist the procedure with crying and kicking ( Tambellini \& Gorayeb, 2003). In dental care there is a great relationship with anxiety, stress and often with pain, with which children evaluate the treatment as a threat to their safety (Cardoso \& Loureiro, 2005).

Pediatric dentists and dental surgeon must be aware that evolution of the treatment, depends on the behavior of the child, so it is often not possible to carry out the scheduled planning, due to the behavior of the patient, ie, who ends up controlling the session Is the child and not the professional (Possobon, Carrascoza, Morais \& Costa Jr, 2007). Thus, it can be created a concept of fear of going to the dentist when the child has already witnessed a negative dental treatment and confirmed their conceptions. Certain postures and the way that the professional presents itself happens to the child many times, that this procedure generates suffering, and that she will have to exert herself to overcome the situation presented and that everything will depend exclusively on her, without any adult can help -over there (Pinto \& Carvalho, 2002).

Due to their own dental experiences, the parents or guardians of the child influence their behavior of fear and anxiety, and may or may not favor care (Felix, Brun, Barbosa \& Barbosa, 2016). Therefore, those parents or guardians who receive guidance prior to treatment can obtain better collaboration by improving the professional's performance (Shitsuka, Friggi, Volpini, 2019), Since parental anxienty can reflect in child's behaviour (Meira Filho, Araujo, Menezes \& Garcia, 2009). Furthermore, the application of Children's Experiences of Dental Anxiety Measure allows the child, parents and dental team to work together to break the vicious cycle of anxiety (Porritt et al., 2021). Nowadays, the number of mothers who wish to attend the service together with their children has increased, however, professionals prefer the absence of the mother at that moment, because their presence makes it difficult to care for the child, influencing their behavior in a negative way And also prologuing working time (Oliveira, Brusco, Brusco, Perussolo \& Patussi, 2010)

The way a child behaves is important in child dental care. To accomplish this, the professional must understand some factors that hinder the development of care. These factors depend on the professional, the clinic and the family structure ${ }^{16}$. It is important that the dental surgeon be aware of the correct techniques to control the child's behavior in the office, in order to obtain positive and satisfactory clinical care (Ferreira, Aragão \& Colares, 2009).

The pediatric dentistry is responsible in addition to the patient's oral health, also for his/her psychological evolution. The professional should see the patient in an integral and individual way, in the social and family environment, being thus more prepared following the care in a more humane way (Ramos \& Paiva, 2003). The adequate communication is useful for the patient, feeling more protected and comforted before the treatment, facilitating for the professional the attendance, since the patient is less anxious and calm (Possobon, Carrascoza, Morais \& Costa Jr, 2007).

Several clinicians, from all areas and specialties, seek to have a more humane service, to favor a more positive service (Garbin, Mariano, Machado \& Garbin, 2002). When the uses of management techniques are not effective or because of the short time for their accomplishment, the use of pharmacological agents may be used as an option, mainly in the presence of an emergency (Possobon, Moraes, Ambrozano \& Costa Jr, 2004). The activity of drawing is a recreational form for the child, establishing a relationship of safety with the professional, with favorable consequences. The use of verbalization by creating stories through the drawings provides a better understanding of the patient's anxiety and fear in treatment. However, play activity means not only a source of well-being, but also a great alternative for reducing child resistance (Stutz, 2011).

The use of drawings serves as a nice strategy, where the child was able to expose their feelings and emotions. Expressing their particular world, transpassing their unconscious we allowing knowledge about their intelligence and psychological state (Palla, Nuvvula, Kamatham, 2016).

The procedure of the story-drawings is very used, so over the years there have been great extensions in the scientific area, not limited in the year of creation, but evolving and becoming extremely important in the therapeutic fields (Stutx, 2011). It is very important to ask the child about the drawing she has done, giving additional information. Pediatric dentists should be 
aware of what the drawing has to say. Therefore, design as non-verbal communication is a positive and adequate method for professionals who attend children (Hanna, Araujo, Gabriel \& Nogueira 2009). Drawing for the child is a recreational activity, being an efficient way to expose your vision related to clinical care. This is important to understand the efficient practice of dentistry in different settings (Bottan, Silva, Matos, Silveira \& Schimitt, 2013). The Social Representations collaborate to understand the relation of the children to the procedure, and this theory contributes with information of values, emotions and conceptions specific to each child involved in the treatment (Alves, 2005). It can be seen that social representations provide a general understanding of a group, and convey creative power, imagination, and their relation to everyday life (Alves, 2005).

Scientific studies aimed at non-pharmacological control of child behavior should always be stimulated. In the area of Pediatric Dentistry there is still much to explore in regard to psychology and associated factors. The methodology of drawings and social representations is also little used in dentistry, and few studies have been found in this literature, mainly related to fear and the difficulty of collaboration in pediatric dentistry care. This study is justified by the fact that it can contribute to the understanding of the child's vision regarding the role of the dental surgeon and the dental environment, thus enabling the adult to overcome the reality of the child's world.

This study aims to interpret the perception of children about the dental surgeon through the analysis of drawings and verbal characterization.

\section{Methodology}

\subsection{Type of study}

This was a cross-sectional observational study, which evaluated the design of children who underwent dental treatment.

\subsection{Patient selection, places of the study and data collect}

All procedures has been approved by local Ethical Committee (Protocol number 1.181.377).

One hundred and eight children attended this research between ages of 5 to 11 years old. Fifty nine were patients of Pediatric Dentistry Clinic of West Sao Paulo University and forty nine were children who are not under dental treatment.

Children who is under dental treatment were asked to make a drawing at the reception room which represent their view of the dentist's figure. On the other hand, children who is not under dental treatment were asked at classroom to make the drawing. Free hand drawings were made with grafite pencils, crayons and rubber in a White A4 sheet.

Were only included in the research, drawings that were focused in the theme, were concluded and clear for interpretation.

It's a quali-quantitative study, in which psychological interpretation was done by a psychologist. Drawings were classified between nice and hostile. Some aspects were evaluated such as: presence of curve lines that express fear, size of doll which representes child, that means that the bigger more affective, space ocuppied, because a shy children draws himself little in the middle of page. Colours also means feelings such as red is hostile and agression, blue means harmony and introversion, green and violet indicate tension, while abscense of colours means abscense of feelings.

\subsection{Data Analysis}

The data were grouped in Microsoft Office Excel spreadsheet and performed statistical analysis in the software Biostat 4.0, where it was used for the relationship of gender between the groups and the psychological relationship between the groups the Fisher's exact test. For the comparison between gender and psychological analysis of both groups, logistic regression was used, and the comparison between gender and psychological analysis of the school and the clinic separately was used for simple logistic regression. 


\section{Results}

In this study were evaluated 108 children, 49 who were not under dental treatment and 59 under dental treatment. From the first group, 26 were male and 23 were female. And in the other one, 22 were male and 37 were female (table 1). There was no statistically significant difference between genders ( $p>0,05)$.

It can be observed between 108 drawings, 37 were classified as hostile from children of the group that is not under dental treatment, while it could be seen 25 in the other group. Variable nice was seen in 12 children from the first group and 34 of the second one (table 2). A statistically significant difference was observed between the groups evaluated $(\mathrm{p}<0,05)$.

Table 1 - Relationship between gender and groups.

\begin{tabular}{c|ccc} 
& Male & Female & Total \\
\hline $\begin{array}{c}\text { No under } \\
\text { treatment }\end{array}$ & 26 & 23 & 49 \\
$\begin{array}{c}\text { Under } \\
\text { treatment }\end{array}$ & 22 & 37 & 59 \\
Total & 48 & 60 & 108
\end{tabular}

(Fisher' test; $\mathrm{p}=0,0738)$. Source: Authors.

Table 2 - Psychological relationship in groups.

\begin{tabular}{l|lll}
\multicolumn{2}{c}{ Nice } & Hostile & Total \\
\hline $\begin{array}{l}\text { Not under } \\
\text { treatment }\end{array}$ & $12(24,5 \%)$ & $37(75,5 \%)$ & $49(100 \%)$ \\
$\begin{array}{l}\text { Under } \\
\text { treatment } \\
\text { Total }\end{array}$ & $34(57,6 \%)$ & $25(42,4 \%)$ & $59(100 \%)$ \\
& 46 & 62 & 108
\end{tabular}

(Fisher's test; $\mathrm{p}=0,0005)$. Source: Authors.

In Graphic 1, it has bens compared psychological profile (nice or hostile) between gender (male or female). It was verified girls show more hostile perception than boys $(\mathrm{p}>0,0346)$. When separating groups, in children who are not under dental treatment no difference could be seen between gender ( $p>0,6741$ ) (Graphic 2), and in children under dental treatment, girls show more hostile perception than boys ( $p>0,0129)$ (Graphic 3). 
Research, Society and Development, v. 10, n. 9, e38710918146, 2021

(CC BY 4.0) | ISSN 2525-3409 | DOI: http://dx.doi.org/10.33448/rsd-v10i9.18146

Graphic 1 - Psychological profile between gender.

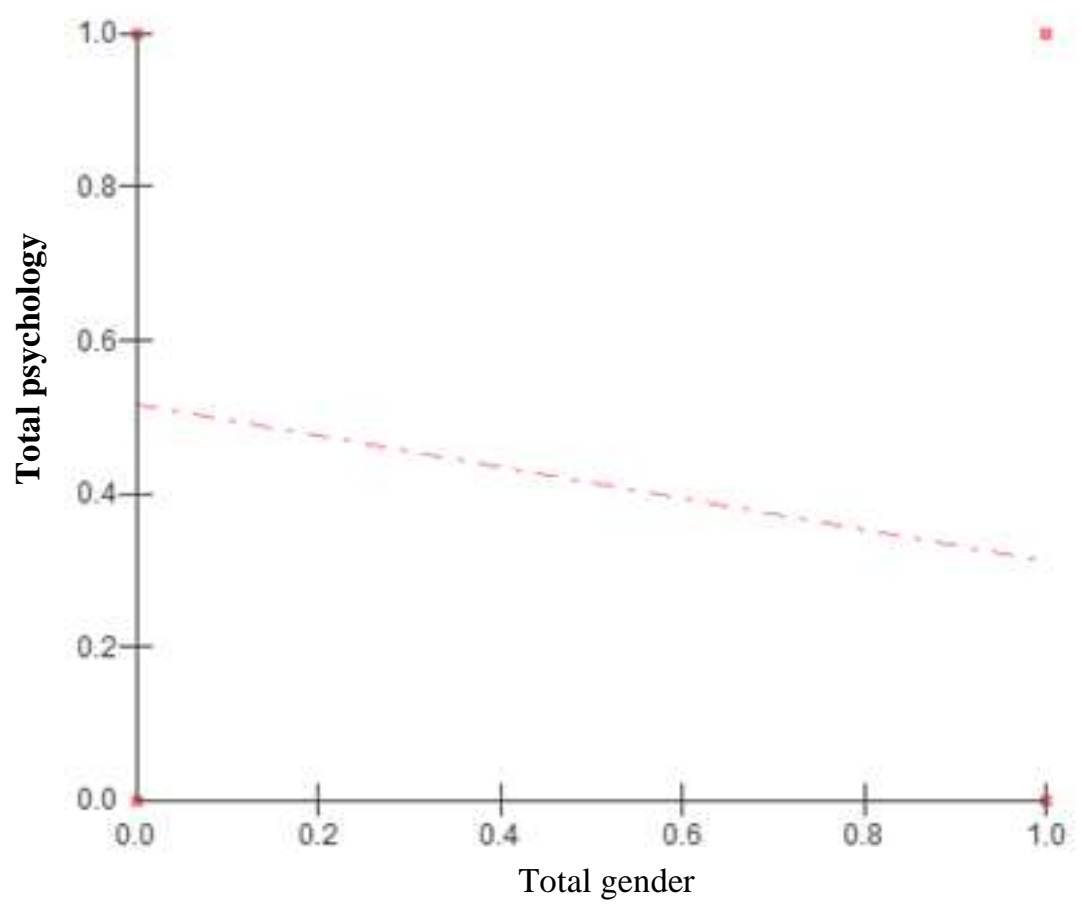

$(p=0,0346)$

Source: Authors.

Graphic 2 - Comparison between gender and school psychological analysis.

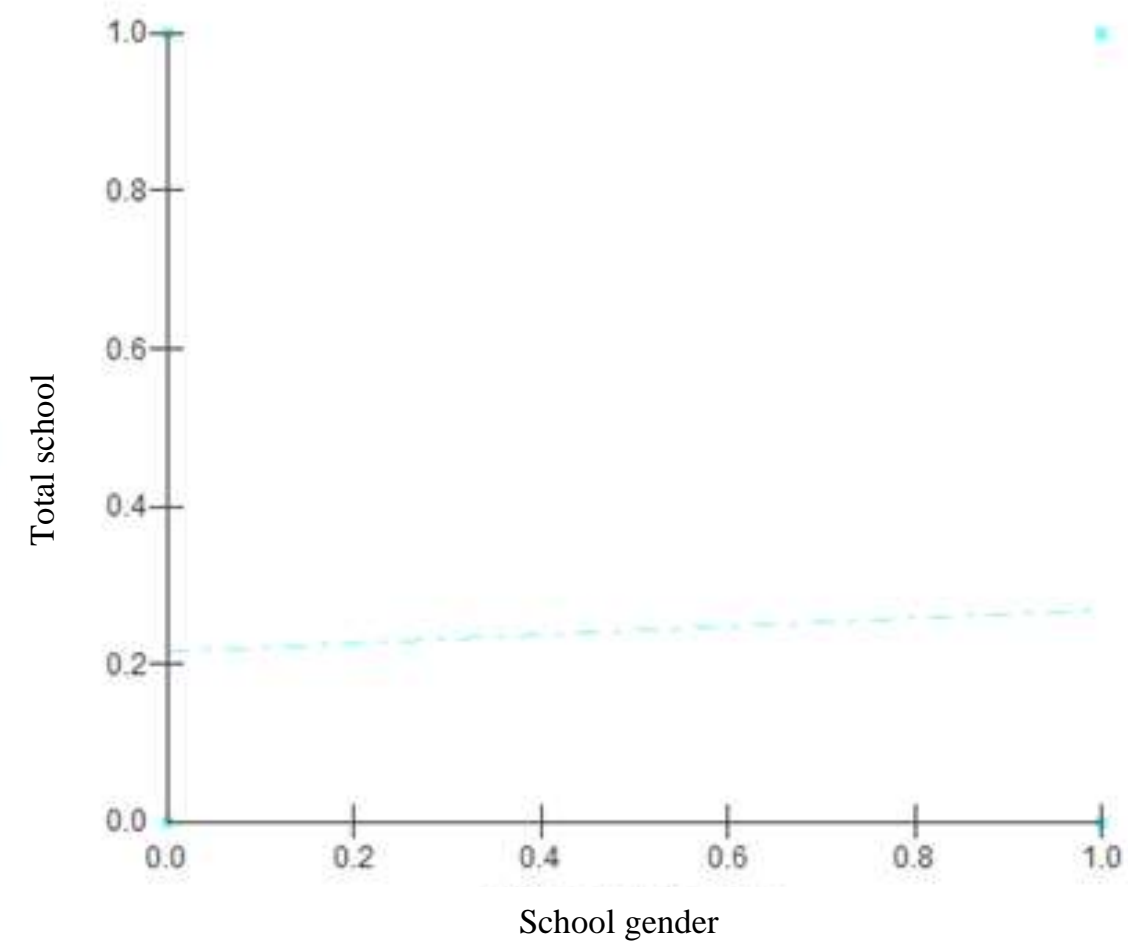

$(p=0,6741)$

Source: Authors. 
Graphic 3 - Comparision betwen gender and clinical psychological analysis.

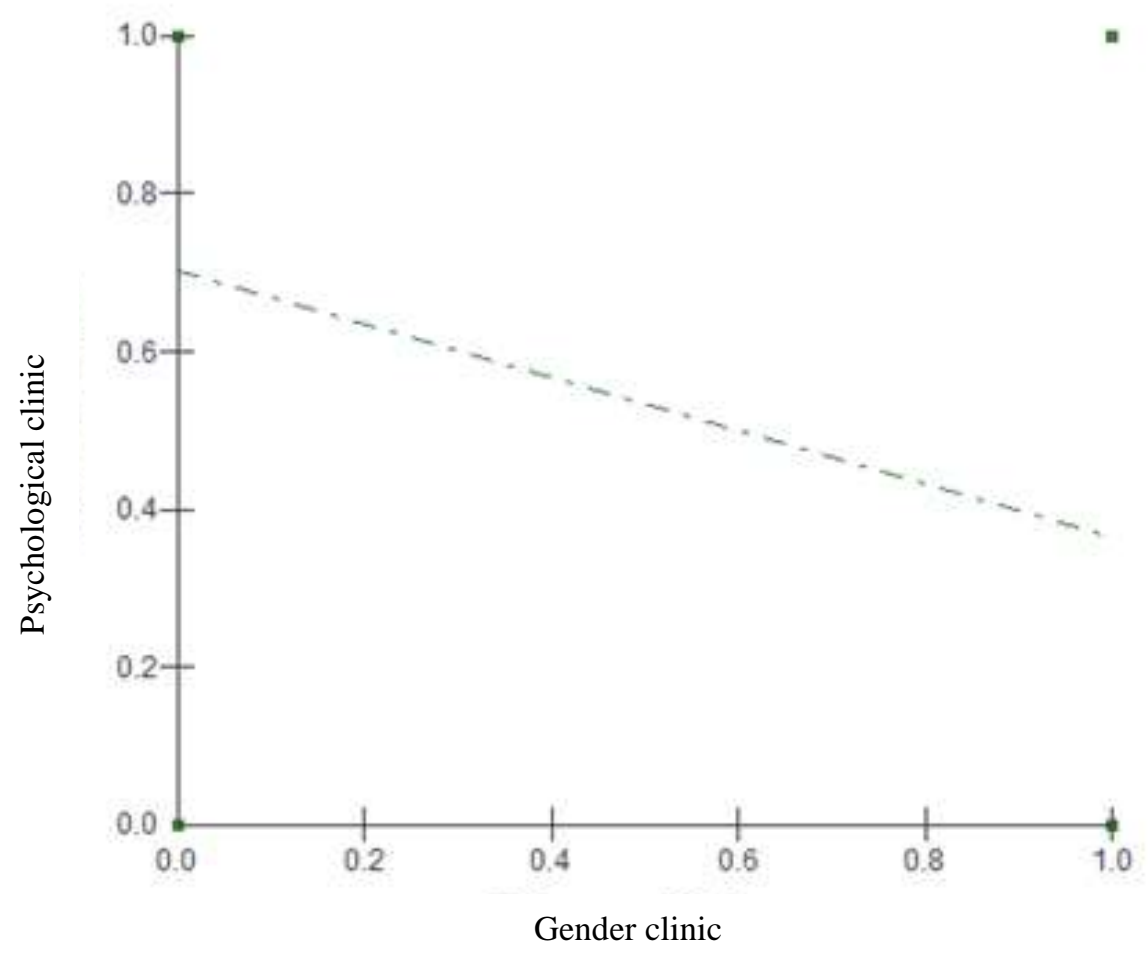

$(\mathrm{p}=0,0129)$

Source: Authors.

In Figure 1, it can be seen some samples of nice and hostile drawings. A, B, C and D drawings are classified as nice; $\mathrm{A}$ and $\mathrm{C}$ express good affectivity as the presence of sun, in C, both dolls are smiling. In B shows treatment receptivity and adaptable behaviour. Besides in D children made drawing in the middle of page and with lots of colours indicating adaptable behaviour.

Drawings E, F, G e H were classified as hostile. Drawing E shows bigger than other, suggesting difficult of relationship, with anxiety and aggression, and the use of rubber suggest insatisfaction and indecision. In F, although it is colourful, show high level of anxiety and defensive attitude, needing mother's presence, as it can be seen with presence of the house. In G, there was an ambivalence of feelings regarding the treatment, expressed mainly on the face of the child, with a face of astonishment, and numerous erasures and corrections that indicate insecurity, while the drawing $\mathrm{H}$ expresses through the pressure of the traces in the present drawing, tension and aggressiveness, Indicating high anxiety. 
Figure 1 - Samples of nice drawings (A, B, C e D) and hostile ones (E, F, G e H).

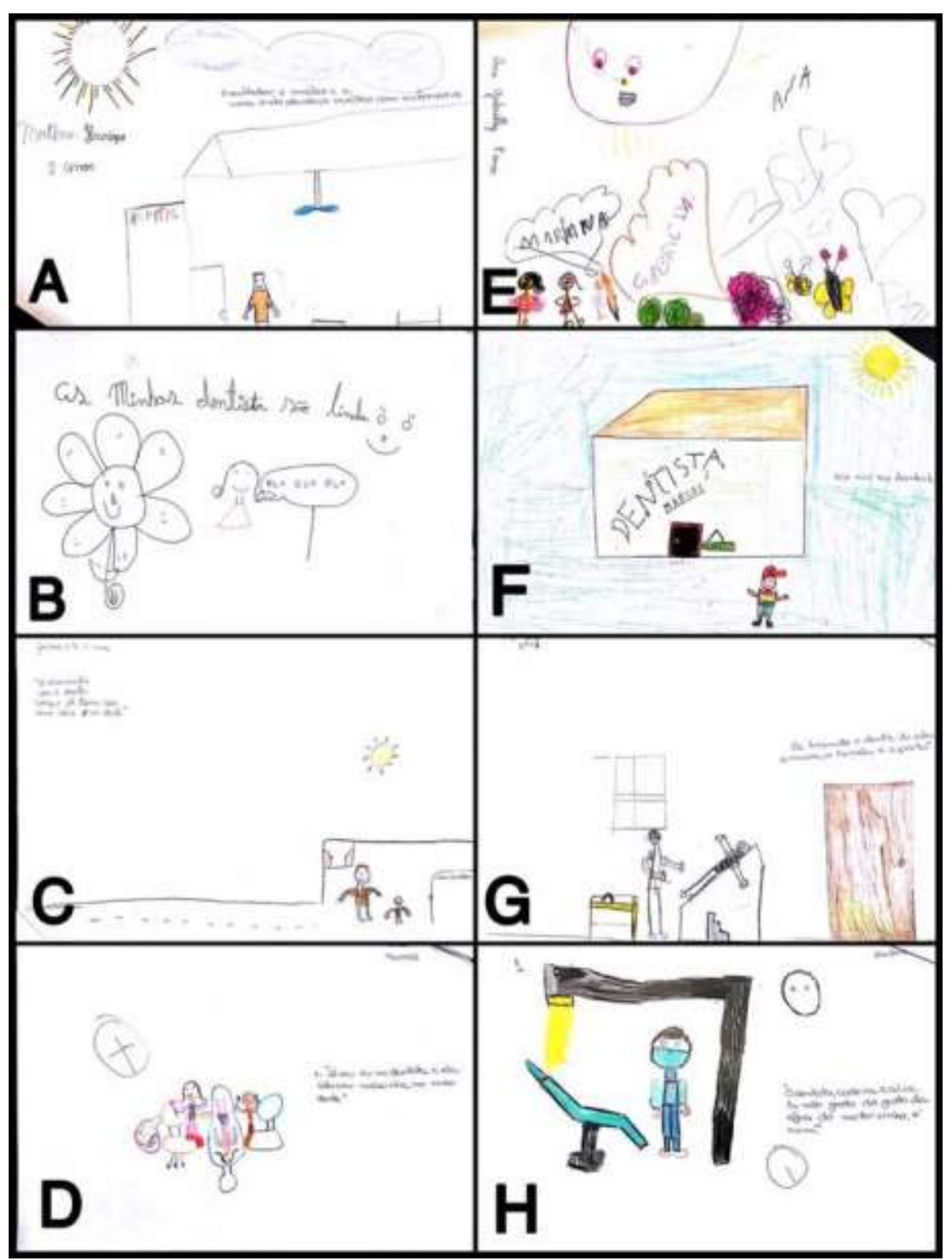

Source: Authors.

\section{Discussion}

Child's fear is associated with death or injury, and it can be associated to dental treatment, also making the treatment more difficult (Mores, Ambrosano \& Possobon, 2004). For the child's normal development, fear is essential. It is transiente and does not cause harm to the daily routine of the child. Biological response to fear is acquired during schooling. Fear to dental treatment is bigger than tooth illness is instaled, mainly in emergency procedures (Singh, Moraes \& Ambrosano, 2000).

Studies show that there is no statistically significant difference between levels of fear, anxienty and gender (Andrade, Laureano, Farias, Fernandes e Cavalcanti, 2020; Andrade, Minhoto, Campos, Gomes, Garcia \& Ferreira, 2013; Aminabadi \& Oskouei, 2011; Cesar, Moraes, Milgrom \& Kleinecht, 1993) which agree with results of the present study. Although, some authors demonstrate bigger levels in male than female (Oba, Dulgergil \& Sonmez, 2009; Pala, Nuvvula \& Kamatham 2016; Singh, Moraes \& Ambrosano, 2000), otherwise some verified highest occurency in girls (Mores, Ambrosano \& Possobon, 2004), it can prove that girls have a greater tendency to anxiety-related behaviors in relation to gender and behavior. 
A comparative study between public and private schools, verified that children who study in public ones does not have a regularly visit to the dentist (Moraes, Ambrosano \& Possobon, 2004), which explain more occurence of hostile pattern. Patients evaluated in this study which were under dental treatment had usual professional contact, leading to the occurence of a better view of the professional. Mittal and Sharma (2012) find results that indicate positive perception to treatment, as Barbieri, Frota and Aguiar, (2010) who observed worst results in public schools. Besides Andrade et al. (2013) reached to negative perceptions to the dentist.

Positive aspects were seen by Bottan, Silva, Matos, Silveira and Schimitt, (2013), when analysing story-drawing in a pediatric dentistry clinical at university. The scene of a university school shows tranquility and empathy, allowing the development of a relationship of trust and good communication between academics and children. Efforts should be made to expand approaches to the child, and the use of images and drawings may facilitate this process (Feigal, 2001). Drawing for the child is like playing, making it possible for their analysis to allow the perception of the child's vision of the dental situation ${ }^{21}$. The use of drawing as an alternative in children with phobia can allow greater access of the professional to the child's vision, allowing an individual approach and analysis of the child's personality (Klinberg \& Broberg, 2007). The drawing-stories procedure was introduced by Walter Trinca in 1972 and systematized in 1976. The drawing is a tool that can be used to measure the child's emotional status, is easy to access and perform, family use and a collection form of the child's perception, entering the unconscious of the child (Aminabadi \& Ouskouei, 2011).

Drawing associated to history can be used as an intervention strategy to decrease child's anxienty to dental treatment (Stutz, 2011).

Drawing hability is predictable, following patterns, that can be measurable. Drawing can also be used in stressful situation, to district children after proceeding, changing their mood and feeling (Palla, Nuvvula \& Kamathan, 2016). Psychological analysis of the drawings shows more between them, hiding unconcious activity, such as breeding and production of the unconscious of the represented object (Marques, Gradvohl, Maia, 2010).

Surgeon should use the psychological techniques to increase confidence and comunication. As caregivers, we must act as actors, teachers, guides and counselors, always with the ultimate goal of child well-being (Feigal, 2001; Aartman, Everdigen, Hoogstraten \& Schuurs, 1996).

The multiprofessional care of the child, involving mainly psychology, can improve their quality of life (Patti \& Meneses, 2005; Cardoso \& Loureiro, 2008). Through a greater understanding of the world of children, the dental experience can be experienced in a more pleasant and educational way (Marques, Gradvohl, Maia, 2010).

In this study, children who presented behavior aversive to dental treatment, after consultation, or after the approach, were invited to watch a cartoon with a dental theme in which the playful illustration of the most positive expression to the attendance and the figure of the dentist. The children who, after the analysis of the drawing by the psychologist, were diagnosed with some behavior disorder, were referred to psychological treatment.

\section{Conclusion}

Analysis of drawings and verbal characterization can be used as a resource for the evaluation of the child's perception regarding dental treatment. When evaluating them, it can be concluded that there was a statistically significant difference between the groups evaluated, and the children of the female gender were more aversive to dental treatment. In future studies, we intend to assess and associate the oral condition of childhood patients through drawings. We still intend to evaluate the drawings in children participating in preventive programs. 


\section{References}

Aartman, I. H. A., Everdingen, T., Hoogstraten, J. \& Schuurs, A. H. B. (1996) Appraisal of Behavioral Measurement Techniques for Assessing Dental Anxiety and Fear in Children: A Review. Journal of Psyshopathology and Behavioral Assessment,18(2).

Alves, R. D. (2005) O tratamento odontológico sob o olhar da criança: um estudo de representações sociais. Course conclusion work (TCC), Rio Grande do Norte: Universidade estadual do Rio Grande do Norte centro de ciências da saúde.

Aminabadi, N. A. \& Oskouei, S. G. (2011) Can drawing be considered a projective measure for children's distress in paediatric dentistry? International Journal of Paediatric Dentistry, 21:1-12.

Andrade, D. S. P., Minhoto, T. B., Campos, F. A.T., Gomes, M. C., Garcia, A. F.G. \& Ferreira, J. M. S. (2013) Percepção infantil através de desenhos e caracterização verbal sobre o cirurgião- dentista. Arq Odontol, 49(4):184-90.

Andrade, N. M., Laureano, I. C. C., Farias, L., Fernandes, L. H. F., Cavalcanti, A. L. (2020) Schedule - Dental Subscale Dental fear in schoolchildren: a pilot study using the Children's Fear Survey Schedule - Dental Subscale. Research, Society and Development, 9 (5): e26953124.

Barbieri, C. M., Frota, F. D. S. \& Aguiar, S. M. H. C. A. (2010) A cárie dentária e a imagem do dentista sob a ótica infantil. Revista Odontológica de Araçatuba, 31(1):16-21.

Bottan, E. R., Silva, F. A., Matos, R.X., Silveira, E.G. \& Schmitt, B. H. E. (2013) Visão do paciente infantil perante atendimento odontológico em clínica universitária. Rev Faculdade de Odontologia de Lins, 23(2):17-24.

Cardoso, C. L. \& Loureiro, S. R. (2005) Problemas comportamentais e stress em crianças com ansiedade frente ao tratamento odontológico. Estudos de psicologia, 22(1):5-12.

Cardoso, C. L. \& Loureiro, S. R. (2008) Estresse e comportamento de colaboração em face do tratamento odontopediátrico. Psicologia em Estudo, 13(1):13341 .

Cesar, J., Moraes, A. B., Milgrom, P. \& Kleinknecht, R. A. (1993) Cross validation of a Brazilian version of the Dental Fear Survey. Community Dent Oral Epidemiol, 21(3):148-50.

Feigal, R. J. (2001) Guiding and Managing the Child Dental Patient: A Fresh Look at Old Pedagogy. Journal of Dental Education, 65(12).

Felix, L. F., Brun, S. L., Barbosa, C. C. N. \& Barbosa, O. (2016) Aspectos que influenciam nas reações comportamentais de crianças em consultórios odontológicos. Revista Pró-UniverSUS, 7(2):13-6.

Ferreira, J. M. S., Aragão, A. K. R. \& Colares, V. (2009) Técnicas de controle do comportamento do paciente infantil. Pesq Bras Odontoped Clin Integrada, $9(2): 247-51$.

Garbin, C. A. S., Mariano, R. Q., Machado, T. P. \& Garbin, A. J. I. (2002) Estudo bioético das relações humanas no tratamento odontológico. Rev Faculdade de Odontologia de Lins, 14(1):54-9.

Hanna, L. M. O., Araújo, R. JG, Gabriel DP, Nogueira AJS. O perfil do dentista sob o olhar infantil. Rev Científica ESAMAZ. 2009. 1(1):24-39.

Klingberg, G. \& Broberg, A. G. (2007) Dental fear/anxiety and dental behavior management problems in children and adolescents: a review of prevalence and concomitant psychological factors. International Journal of Paediatric Dentistry, 17:391-406.

Laureano, I. C. C., Farias, L., Fernandes, L. H. F., Alencar, C. R. B., Forte, F. D. S., Honório, D. R., Cavalcanti, A. L. (2020). Brazilian Dental Journal. 31(6): 673-679.

Marques, K. B. G., Gradvohl, M. P. B. \& Maia M. C. G. (2010) Medo e ansiedade prévios à consulta odontológica em crianças do município de Acaraú-CE. RBPS, 23(4):358-67.

Meira Filho, M. M. O., Araújo, D. T. C., Menezes, V. A. \& Garcia, A. F. G. (2009) Atendimento odontológico da criança: percepção materna. RGO, 57(3):311-5.

Milson, K. M., Tickle, M., Humphris, G. M. \& Blinkhorn, A. S. (2003) The Relationship between anxiety and dental treatment experience in 5-year-old children. British Dental Journal, 194:503-6.

Mittal, R. \& Sharma, M. (2012) Assessment of psychological effects of dental treatment on children. Contemporary Clinical Dentistry, 3(1):2-7.

Moraes, A. B. A., Ambrosano, G. M. B. \& Possobon RF. (2004) Fear Assessment in Brazilian Children: The Relevance of Dental Fear. Psic Teor E Pesq, 20(3):289-94.

Oba, A. A., Dulgergil, C. T. \& Sonmez, I. S. (2009) Prevalence of Dental Anxiety in 7- to 11 - Year- Old Children and Its Relationship to Dental Caries. Med Princ Pract, 18:453-7.

Oliveira, D. A., Brusco, E. H. C., Brusco, L., Perussolo, B. \& Patussi, E. (2010) Avaliação da Preferência dos Pares Mãe-Filho Quanto a Presença Materna Durante o Atendimento Odontopediátrico. Pesq Bras Odontoped Clín Integrada, 10(1):89-93. 
Research, Society and Development, v. 10, n. 9, e38710918146, 2021

(CC BY 4.0) | ISSN 2525-3409 | DOI: http://dx.doi.org/10.33448/rsd-v10i9.18146

Oliveira, F. C. M. (2008) Compreendendo a fobia em odontopediatria por meio de intervenções com o Procedimento de Desenhos-Estorias. Course conclusion work (TCC), São Paulo: Instituto de Psicologia da Universidade de São Paulo.

Oliveira, M. F., Moraes, M. V. M. \& Cardoso, D. D. (2012) Avaliação da ansiedade infantil prévia ao tratamento odontológico. Publ UEPG Ci Biol Saúde, 18(1):31-7.

Pala, S. P., Nuvvula, S. \& Kamatham, R. (2016) Expression of pain and distress in children during dental extractions through drawings as a projective measure: A clinical study. World J Clin Pediatr, 5(1):102-11.

Patti, E. A. M. R. \& Meneses, I. C. (2005) Crianças com sintomas fóbicos e o tratamento odontológico. Rev Científica da Universidade de Franca, 5(1/6):92100.

Pinto, M. R. S. \& Carvalho, M. R. (2002) Diagnóstico e prevenção do estresse do paciente em odontopediatria. In: Corrêa MSNP. Sucesso no Atendimento Odontopediatríco: Aspectos Psicológicos. 1.ed. São Paulo: Santos; 59-67.

Possobon, R. F., Carrascoza, K. C., Moraes, A. B. A. \& Costa Jr, A. L.(2007) O tratamento odontológico como gerador de ansiedade. Psicologia em estudo, 12(3):609-16.

Possobon, R. F., Moraes, A. B. A., Ambrozano, G. M. B. \& Costa Jr, A. L. (2004) O comportamento de crianças em tratamento odontológico: intervenção psicofarmacológica. Psicologia em estudo. 2004; 9(1):29-35.

Porritt, J. M., Morgan, A., Rodd, H., Gilchrist, F., Baker, S. R., Newton, T., Marshman, Z. A Short Form of the Children's Experiences of Dental Anxiety Measure (CEDAM): Validation and Evaluation of the CEDAM-8. (2021) Dent J (Basel), 15;9(6):71.

Ramos, M. L. J. \& Paiva, S. M. (2003) Comportamento infantil no ambiente Odontológico: aspectos psicológicos e sociais. J Bras Odontopediatr Odontol Bebê, 6(29):70-4.

Salem, K., Kousha, M., Anissian, A., \& Shahabi, A. (2012) Dental Fear and Concomitant Factors in 3-6 Year-old Children. J Dent Rest Dent Clin Dent Propect, 6(2):70-4.

Singh, K. A., Moraes, A. B. A. \& Ambrosano, G. M. B. (2000) Medo, ansiedade e controle relacionados ao tratamento odontológico. Pesq Odont Bras, 14(2):131-6.

Shitsuka, C., Friggi, M. N. P., Volpini, R. M. C. (2019) Influence of parents on child behavior in dental care. Research, society and development, 8(7): E43871154.

Stutz, B. L. (2011) Explorando o desenho para redução da ansiedade infantil na sala de espera em odontologia. Em Extensão, 10(2):162-71.

Tambellini, M. M. \& Gorayeb, R. (2003) Escalas de medo odontológico em crianças e adolescentes. Paidéia,13(26):157-61. 